\title{
NOTES OF THE QUARTER.
}

(July, August, September, 1891.)

I. Obituary Notices.

Colonel George Edward Fryer, of the Royal Asiatic Society, whose decease we notice in the present issue of our Journal, was the eldest son of the late Colonel George Fryer, for several years Military Secretary to the Government of Fort Saint George. He was born on the 25th of November, 1832 , and received his education at Rugby. Shortly after attaining the age of twenty, young Fryer entered the Military Service of the Honourable East India Company, his first commission as Ensign bearing date the 20th of January, 1853. After spending about eight years and a half with his regiment, the 21st M.N.I., he was attached for a short time to the Police Department in the District of Canara; subsequently to the Department of Public Works in Arcot; and finally, in January, 1864, was sent over to British Burma, where he worked, first, for about a year, as a District Police Officer, being afterwards transferred to the British Burma Commission, at about the time when he got his Captaincy in the Madras Staff Corps. Colonel Fryer, thereafter, by seniority, rose to the grade of Deputy Commissioner, performing civil and Judicial duties, until, retiring from active employment, he returned on permanent furlough to England, where he continued to reside during the remainder of his life. Preferring literary pursuits to the other more ordinarily followed ways of relaxation in India, Colonel Fryer devoted 
his leisure time chiefly to the acquisition of Oriental languages. Besides Hindoostanee and Burmese, of which he had a competent knowledge, he applied himself to Pāli, which he studied critically, contributing several articles on the same to the Asiatic Society of Bengal; such as: (i.) Pāli Studies, No. 1. Analysis and Păli Text of the Subodhalankara, or "Easy Rhetoric," by Sungharakkhita Thera (Journ. xliv. part i. p. 91). (ii.) Pãli Studies, No. 2. Vuttodaya, “Exposition of Metre," by Sanghrakkhita Thera, edited with translation and notes (Journ. xlvi. part i. p. 369). (iii.) Letter on the Tradition as to Păli being the Original Language (Proc. 1879 , p. 155). (iv.) Letter forwarding copies of two Buddhist Inscriptions, in Old Sanskrit characters, found in the Sandoway District, Arakan (Proc. 1879, p. 201). (v.) Note on the Pāli Grammarian Kaccayana (Proc. 1882, p. 119). (vi.) Note on a Burmese copy of the Kaläpa Grammar (Proc. 1885). In respect to the above, it may here be noticed that Colonel Fryer left behind him a select collection of Pāli palm-leaf books very methodically arranged. That his reading was extensive and varied is shown by the following other papers on more general subjects which were also the product of his pen. (1.) A Contribution to our Knowledge of Pelagic Mollusca (Journ. xxxviii. part ii. p. 259). (2.) On Burmese Celts (Proc. 1872, p. 96). (3.) Note on an Arrakanese Coin (Journ. xli. p. 201). (4.) On the Khyeng people of the Sandoway District, Arakan (Journ. xliv. part i. p. 39). These latter were also sent to the Asiatic Society of Bengal.

For the Royal Asiatic Society he wrote, "A few Words concerning the Hill People inhabiting the Forests of the Cochin State" (Journ. Vol. III. Part II. New Series, Art. XII. p. 478). Colonel Fryer brought out besides, in 1866 and 1867, two useful compilations, viz. (1) a Handbook of British Burma ; and (2) Questions and Answers on Police Duties (English and Burmese). As a Member of the Royal Asiatic Society he was one of those who were deputed, the year before last, to attend the Oriental Congress held 
in Sweden. Colonel Fryer's death was sudden and unexpected. His decease was greatly regretted by those who knew him as not only a man of varied talents, but also of kindly disposition and courteous manners. $\mathrm{He}$ was married in December, 1857, to Georgina Katherine Phelan, who survives him, as do also two sons, who, following their father's footsteps, are officers in the Indian Staff Corps; and two daughters, one married to Captain Claude Tennant, likewise of the Indian Staff Corps.

\section{R. D. Ardagh.}

Ahmed Vefik Pasha, an Honorary Member of the Society, died in April. He was for many years a prominent statesman, patriot, and scholar. His literary labours were extensive in a variety of lines, but it would be difficult to furnish anything like a complete list of his works, as many were written anonymously. His most important work is a Dictionary of the words of Turanian origin used in the Turkish language. It is called "Lehjet-ul-Lughat," and is a work of very considerable value, and has been used by M. Barbier de Meynard as the basis for his "Supplément aux Dictionnaires Turcs."

Vefik Pasha also wrote a short history of Turkey, and translated a number of Molière's plays into Turkish. He occupied a position by himself in the Turkish literary world, holding aloof alike from the reactionary party who oppose all change, and from the revolutionary school, which, headed by Kemāl Bey and by Hāmid Bey, is endeavouring to introduce Western modes of thought and expression into Turkish literature. This modern school has now practically won the day. 